\title{
The Impact of Teacher, School, and Student Factors on Standardized Student Test Scores Using Multidimensional Approach
}

\author{
S. Maarouf
}

\section{ABSTRACT}

This study examines the effect of teacher (race, salary, and experience), school (climate and Financial Efficiency Star Rating), and student (attendance and mobility) factors on student Math and ELA standardized test scores in elementary $(n=1140)$ and middle $(n=451)$ public schools across the state of Georgia. The data used in this study was collected by Georgia Department of Education (GaDOE) during the 2018-2019 school year. Three multivariate linear regression models are utilized to explore the main and interaction effects within and between factors. The first model analyzes the main effects of the three independent variables (teacher, school, and student) separately and then in a single combined model accounting for all factors. Individual model approach reveals strong positive correlations with Math and ELA test scores for all factors. However, the impact of each factor is greatly diminished in a combined model approach. The second model reveals that the interaction effects within factors does not impact student test scores significantly. Meanwhile, results from the third model show that the interactions between the three independent variables yield a modest impact on student test scores. Findings from this study can guide educators and policymakers to focus on factors that can improve student standardized test scores and meet the accountability mandate for school achievement as set by the Every Student Succeeds Act (ESSA) of 2015 and its predecessor No Child Left Behind (NCLB) Act of 2001.

Keywords: Academic Achievement, Multivariate Linear Regression, School Resources, Standardized Testing, Teacher Quality

\section{INTRODUCTION}

In the state of Georgia, students in grades 3 through 8 must take the Georgia Milestone tests, an end-of-grade (EOG) summative assessment, in the content areas of ELA, math, science, and social studies (Georgia Department of Education, nd). The Georgia Milestone Assessment System (GMAS) was implemented in 2015 and replaced the retired Criterion-Referenced Competency Tests (CRCT), which the State used for 15 years. The GMAS tests are more meticulous and demanding than CRCT tests (Price, 2019). They are constructed to challenge students beyond simply choosing one correct answer from a multiple choice. In some cases, students must find the correct answer themselves rather than selecting it. In other cases, students must explain how they got their answers or yet why a given answer is wrong. Third grade students must pass ELA to move to fourth grade whereas fifth and eighth grade students must pass ELA and math subjects to move to the next grade (Georgia Department of Education, nd). The GMAS tests are designed to challenge schools, teachers, and students to study the core subjects for
Published Online: January 14, 2022

ISSN: $2736-4534$

DOI :10.24018/ejedu.2022.3.1.177

S. Maarouf

Columbus State University, Columbus, USA

(maarouf_saoussan@ ${ }^{@}$ columbusstate.edu) the duration of the school year. They are not the type of tests where students can simply get by if they only spend a short period of time preparing prior to the tests, especially for questions where students are required to provide writing responses (Price, 2019). The GMAS tests are adopted from the national Common Core State Standards (CCSS) initiative of 2009, which guides what students should learn in each grade level. As such, the test results are intended to be used by parents, educators, policymakers, and the public in general as an indicator of the efficacy of the educational system at the school and school district level in the state of Georgia (Tagami,2016). In 2019, the State of Georgia was ranked significantly lower than National average score in Math and Writing and at the national average in Reading for Grade 4 (National Assessment of Educational Progress, n.d.).

\section{LITERATURE REVIEW}

Traditionally, summative assessments are used to sort and promote students based on their test scores. Some researchers have argued that the dependence on summative assessment 
practices via standardized tests will not close the achievement score gaps (Chappuis et al., 2020; Orlich \& Gifford, 2006). Recent educational reform policies added immense pressure on schools and teachers to produce higher test scores. Schools and teachers whose students scored low are labelled as "failed" schools and either punished or put on probation, whereas teachers and schools whose students scored high are generally rewarded (Newton, 2017; Darling-Hammond, 2004). As such, educators must be compelled to research factors that contribute to this disparity. In fact, identifying the multifaceted factors that can advance student learning outcomes continues to be a topic of high interest in academic research at both the national and state levels. Consequently, a considerable body of work centered around school, teacher, and student factors has emerged (Cirino et al., 2018; Orlich, 2003).

One factor in question when dealing with students' test scores is teacher quality. Prior research has mostly shown a positive correlation between teacher quality and student achievement (Hanushek, 2018; Dial, 2008). However, the relation between the two is complex and provokes controversy and debate amongst various education stakeholders (Goldhaber, 2008; 2015). The impact of teacher quality on student test scores and achievement spans a continuum of variables such as experience, compensation, licensure, race, and professional development. While considerable number of prior research concluded that teacher experience and mastery in pedagogy can yield gains in student learning and performance, others disputed these findings (Weaver, 2019; Ladd, 2008). Ladd (2008) determined that teachers with 20 years of experience have more impact on student learning than first year teachers, but the impact disappears when compared to teachers with 5 years of experience. Hightower et al. (2011) concluded that teacher experience resulted in positive gains on student learning and their scores on standardized tests. Other studies have shown that other factors such as teacher preparation programs, training, and attrition of teachers may eclipse the advantage of teacher experience (Xu et al., 2011; Boyd et al., 2008). These contradicting conclusions raise questions whether teacher experience by itself a positive contributor to students is test scores or rather an interaction with other contributing factors. Furthermore, disparity in teacher salary compared to other professions has gathered substantial support in the political and public arena. In recent years, a growing number of research was conducted to address the effects of teacher salary on student academic outcomes (Pham et al., 2020; Loeb \& Page, 2000). Pham et al. (2020) conducted a meta-analysis of 44 studies that addressed this topic. They determined that teacher salary had a small positive effect on student test scores. Moreover, many studies have shown that there is inequitable representation of minority teachers in public schools (Yarnel \& Bohrnstedt, 2018; Clotfelter et al., 2005). While prior research has shown that students could academically benefit and their test scores could be improved when they share the same race/ethnicity with their teachers, the imbalance between White and minority teachers still largely exists. This imbalance has provoked an outcry from policymakers at the national and state levels demanding public schools to recruit, hire, and train minority teachers (Joshi et al., 2018; Partelow et al.,
2017).

A second factor that prior research studied its effect on student achievement is school characteristics. Researchers have explored many school inputs and the magnitude of their relations on student achievement. Some of these inputs included student/teacher ratios, expenditures per student, school resources, cultural diversity, leadership, and school environment (Ntobeko, 2018; Savasci \& Tomul 2013.) The findings from such growing body of research were mixed. For example, some studies concluded that there is no significant effect of expenditures per student on test scores. Hanushek (1998) concluded that there is no positive relation between school expenditure and student academic achievement. He argued that due to inefficiencies in school operation increase in expenditures does not necessarily yield better student outcomes. On the other hand, other studies (Jackson et al., 2016; Sun, 2014) determined that school expenditures have positive effect on student educational outcome. School environment has also been studied by prior research with a general consensus that school environment positively affects academic achievement and is a leading factor in explaining student test scores and learning (Dulay \& Karadağ, 2017; Jimenez-Castellanos, 2010). The findings from such growing body of research should guide policymakers to allocate school funding according to school quality and performance. Parents are inclined to search for better schools for their children, and hence to move to school districts that offer safe environment and generate more tax revenue to support student education (Ostrander, 2015).

A third factor of a great concern for school administration regarding its impact on test scores is associated with students' attributes. Some of these attributes include attendance, mobility, race, socio-economic status, English proficiency, and special needs students. For instance, attendance has long been considered as a key contributor to student achievement and success. The research on this topic has increased in recent years due to school accountability and NCLB legislation (Kim, et al., 2020; Cassell, 2019). Several studies have shown a strong positive link between student attendance and academic performance and graduation rates (Gershenson, 2016; McGahee, 2019; Gottfried, 2010). In addition, student mobility has been studied by prior research with contradicting conclusions. Student mobility has been linked to poor student performance in ELA, Math, and Reading (Sparks, 2016; Eddy, 2011). It has also been determined that student mobility has a detrimental impact on both students and their schools (Rhodes, 2005). Conversely, other research argued that such impact might not be related to student mobility by itself but rather to an interaction with other factors such as socioeconomic status, cultural background, and family structure (Donnelly \& Gamsu, 2018; Welsh, 2017). As family mobility continues to be a major issue in the American society, students are forced to make the proper adjustments (Welsh, 2016). These students normally do not receive the proper attention at school to address the psychological impact of mobility on their academic and social well-being. Teachers tend to spend more time and focus on addressing the needs of the less mobile students since such needs are much more manageable (Eddy, 2011). 


\section{PRESENTSTUDY}

The purpose of this study is to investigate the impact of factors associated with teachers, schools, and students on the overall GMAS Math and ELA test scores in elementary and middle schools across the state of Georgia during 2018-2019 school year. Students attending 3rd through 8 th grades in the state of Georgia are required to take end-of grade tests in the content areas of ELA, Math, Reading, and Social Studies. Each school can select a time period as designated by the State, normally towards the end of school year, to administer these tests. Students can attain the following four achievement levels for each test (Georgia Department of Education, nd):

1) Beginning Learner - Student lacks basic knowledge in content area as required by Georgia's content standards and requires considerable support to be ready for next grade level.

2) Developing Learner - Student demonstrates partial knowledge in content area as required by Georgia's content standards and requires further academic support to be ready for next grade level.

3) Proficient Learner - Student exhibits proficiency in the knowledge needed at this grade level and is prepared for the next grade level.

4) Distinguished Learner - Student demonstrates mastery in the knowledge needed at this grade and is well prepared for the next grade level.

While significant body of research has examined the effects of various variables on student learning and achievement, most of these studies focused on only one variable at a time. The current study offers a more comprehensive approach that accounts for three main independent variables and multiple factors associated with them. Identifying the impact of multifaceted variables and their interaction on standardized test scores is particularly important to the academic development of young students and improvements in school achievement and teacher quality. Research has shown that the impact of such variables can be more profound in the academic development of middle school students. These students are at a higher risk of dropping out from high school at later years if they are not performing well (Balfanz, 2007). Moreover, findings from this study can contribute to the continuous improvement push in public education as mandated by various national and state legislations such as the ESSA Act of 2015 and its predecessor NCLB Act of 2001.

\section{CONCEPTUAL FRAMEWORK}

The conceptual framework for this study is beneficial since it addresses three important conceptual components in elementary and middle schools: (1) the individual relationship between teacher, student, and school factors on student test scores in Math and ELA, (2) the combined impact of teacher, student, and school factors on student test scores in Math and ELA, and (3) the interaction within and between variables. The framework (Fig. 1) is modeled and refined based on prior research findings and the gap in literature that this study is aiming to address by examining the following research questions:

1) To what extent are students test scores in Math and ELA affected by teacher factors (salary, race, and experience)? school factors (climate and FESR rate)? student factors (attendance and mobility rate)?

2) To what extent are students test scores in Math and ELA affected by the combined teacher, school, and student factors?

3) Are there any significant interaction effects within teacher, school, and student variables on student test scores in Math and ELA?

4) Are there any significant interaction effects between teacher, school, and student variables on student test scores in Math and ELA?

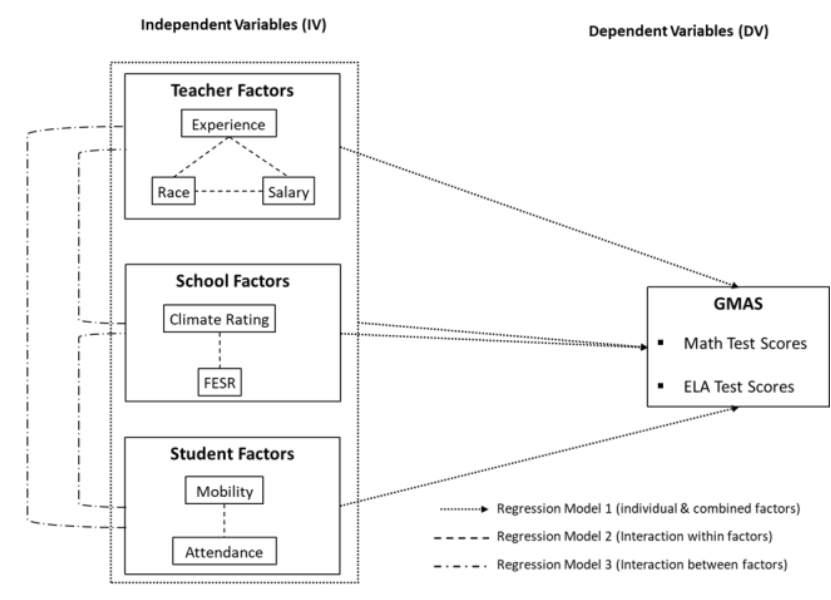

Fig. 1. Conceptual framework.

\section{METHOD}

\section{A. Participants}

The population for this study consists of all elementary and middle public schools in the state of Georgia during 20182019 academic year ( $n=1140$ for elementary schools and $n$ $=451$ for middle schools). The data sources for this study were downloaded from the following websites:

1) Georgia Department of Education (GaDOE): https://www.gadoe.org/Pages/Home.aspx

2) The Governor's Office of Student Achievement (GOSA): https://gosa.georgia.gov

3) There are missing data for 10 elementary schools and 6 middle schools. These schools are dropped from the analyses since the number of missing data is significantly small compared to the total number of public schools in the state of Georgia. The following reports for 2018-2019 academic year are used as basis for analyses in this study:

4) School Score Report Card: GMAS End-of-Grade (EOG) report that tracks student test scores disaggregated by performance levels, student attributes, and grade level for each content area.

5) Certified Personnel Data file: Tracks teacher data related to gender, race, salary, experience, education, and certification.

6) School Climate Rating: This data set includes multiple distinct constructs and comes from diverse sources such as surveys, student records, teacher records, safe environment, substance free, student perception, parent perception, and personnel perception. 
7) School Financial Efficiency Star Rating (FESR): The purpose of this star rating is to provide school spending per student as it relates to academic performance of students averaged over a three-year period. The school rating is based on College and Career Ready Performance Index (CCRPI) and per pupil expenditure (PPE) calculations.

8) Student Attendance: Data are provided by school districts to GaDOE each year using student record.

9) Student Mobility: Data is collected by GaDOE based on the percentage of students admitted or withdrew from a school during one academic year.

\section{B. Measures and Procedures}

Quantitative methods are used to analyze the collected data from GaDOE and GOSA websites. Exploratory research is utilized to identify key teacher, school, and student factors that contribute to student test scores in Math and ELA. This study is also correlational in nature since it attempts to determine relationships between multiple variables as they relate to student test scores. Three multivariate linear regression models are used for two content areas, Math and ELA. The first model explores the main effects of three independent variables (Teacher, School, and Student) on the dependent variable (student test scores). The second regression model explores the interaction effects within each independent variable on student test scores while the third regression model explores the interaction effects between independent variables. For the second and third regression models, the factors for each independent variable are standardized (centered) by subtracting the mean value. To run a regression model analysis with interactions, new factors are created by multiplying the standardized factors within each independent variable for the second model and across independent variables for the third model. Finally, scaled measures are created for the following factors for a better interpretation of the results:

\section{1) Teacher Factors}

The "Certified Personnel Data" report divides teachers' years of experience in 5 subgroups: <1 year, 1-10 years, 1120 years, 21-30 years, and $>30$ years. Table I shows an example calculation for a random school in order to determine its Teacher Experience Rate score. Similar calculation is used for all elementary and middle schools. Since the majority of elementary and middle school teachers in the state of Georgia are White, a race score scale is established according to the percentage of White teachers in each school. The following rate scale is used for each school:

- $0 \%-25 \%=1$ (very low White teacher percentage);

- $25.1 \%-50 \%=2$ (low White teacher percentage);

- $50.1 \%-75 \%=3$ (high White teacher percentage);

- $75.1 \%-100 \%=4$ (very high White teacher percentage).

The teacher salary ranges between $\$ 40 \mathrm{k}$ to $\$ 70 \mathrm{k}$ per year.

A salary scale is used according to the following:

- $\$ 40,000-\$ 50,000=1$;

- $\$ 50,001-\$ 60,000=2$;

- $\$ 60,001-\$ 70,000=3$.

2) School Factors

The Star Climate and FESR reports are available at the state, district, and school level. The Star Climate report assesses and grades each individual climate factor separately. An overall scale of $1-5$ is then used to rate each school, where $1 \mathrm{Star}$ is given to schools in need of most improvement and 5 Stars to schools having an excellent climate. The FESR report uses a scale of 0.5 to 5 stars in 0.5 intervals where a rating of $0.5 \mathrm{Star}$ is given to a school with high spending and low CCRPI and a rating of 5 Stars is given to a school with low spending and high CCRPI (Georgia Department of Education, nd).

\section{3) Student Factors}

The Student Attendance report includes data at the district and school levels showing the percentage of students' absenteeism in 3 distinct levels:

- $0-5$ days (Exemplary);

- $6-15$ days (Acceptable);

- >15 days (Unacceptable).

Table II shows an example calculation for a random school in order to determine its Attendance Rate score. Similar calculation is used for all elementary and middle schools.

The Student Mobility report is also available at the state, district, and school level. The state of Georgia defines a student as mobile if he or she enters or withdraws from school between October $1^{\text {st }}$ and May $1^{\text {st }}$ (Georgia Department of Education, nd). The data in the report ranged between 2 and 63. The following Mobility Rate Score scale is created for the purpose of analysis:

- $<5=5$ (very low mobility rate);

- $5.1-10=4$ (low mobility rate);

- $10.1-20=3$ (average mobility rate);

- $20.1-40=2$ (high mobility rate);

- $40=1$ (very high mobility rate).

\begin{tabular}{|c|c|c|c|c|c|}
\hline $\begin{array}{c}\text { Years of } \\
\text { Experience } \\
\text { (YOE) }\end{array}$ & $\begin{array}{c}\text { Adjusted } \\
\text { YOE } \\
\text { (AYOE) }\end{array}$ & $\begin{array}{c}\text { Number of } \\
\text { Teachers } \\
\text { (\#TEACH) }\end{array}$ & $\begin{array}{c}\text { Scaled Score }(\mathrm{SS}) \\
=\mathrm{AYOE} \mathrm{x} \\
\text { \#TEACH }\end{array}$ & $\begin{array}{c}\text { Average } \\
\text { Experience/Teac } \\
\text { her =SS/\#TEAC }\end{array}$ & $\begin{array}{l}\text { Experience } \\
\text { Rate Score }\end{array}$ \\
\hline$<1$ & 1 & 1 & 1 & & \\
\hline $1-10$ & 5 & 11 & 55 & & \\
\hline $11-20$ & 15 & 21 & 315 & & \\
\hline $21-30$ & 25 & 9 & 225 & & \\
\hline 30 & 30 & 3 & 90 & & \\
\hline Total Score & & 45 & 686 & 15.24 & 2 \\
\hline
\end{tabular}

Note: Rating scale: Low experience (1) 9.00-14.00, Moderate Experience (2) 14.01-19.00, High Experience (3) 19.01-24.00. 
TABLE II: SAMPLe CALCUlation Of STUdENT ATTENDANCE RATE SCORE

\begin{tabular}{ccccccc}
\hline \hline $\begin{array}{c}\% \text { Absent } \\
(0-5 \text { days })\end{array}$ & $\begin{array}{c}\text { Scaled Absence } \\
(0-5 \text { days })\end{array}$ & $\begin{array}{c}\% \text { Absent } \\
(6-15 \text { days })\end{array}$ & $\begin{array}{c}\text { Scaled } \\
\text { Absence } \\
(6-15 \text { days })\end{array}$ & $\begin{array}{c}\% \text { Absent } \\
(>15 \text { days })\end{array}$ & $\begin{array}{c}\text { Scaled } \\
\text { Absence } \\
(>15 \text { days })\end{array}$ & $\begin{array}{c}\text { Scaled School } \\
\text { Absence } \\
(6-15 \text { days })\end{array}$ \\
\hline 59.6 & 149 & 36.2 & 380.1 & 4.2 & 63 & $\begin{array}{c}\text { Student } \\
\text { Attendance Rate }\end{array}$ \\
\hline Total Score & & & & 592.1 \\
\hline
\end{tabular}

Note: Rating scale: Very Low Attendance (1) 801-1000, Low Attendance (2) 701-800, Moderate Attendance (3) 601-700, High Attendance

(4) 501-600, Very High Attendance (5) 300-500.

\section{4) Math and ELA Test Score Measures}

The End-of-Grade (EOG) Assessment's report is used by this study to extract data in relation to how well students are mastering content standards in Math and ELA. The report disaggregates the data by grade level and the percentage of students in each achievement level (Beginning, Developing, Proficient, Distinguished). For the purpose of this study, the Subject Test Score Rate (STSR) for each individual school is calculated according to the following formula:

\section{STSR $=\%$ Beginner $\times 1+\%$ Developing $\times 2+\%$ Proficient} $\times 3+\%$ Distinguished $\times 4$

\section{Data Analysis}

SPSS software is used for descriptive and multivariate inferential analysis using multiple linear regression models. The analyses are done to determine if the student test scores in Math and ELA can be predicted from teacher factors (salary, race, and experience), school factors (climate and FESR rate), and student factors (attendance and mobility rate). The assumption of normality is tested and met via examination of the unstandardized residuals for all regression models. Review of the S-W test for normality, skewness, and Kurtosis suggest that the normality is a reasonable assumption. The boxplots suggest a relatively normal distributional shapes with no outliers of the residuals. The Q$\mathrm{Q}$ and histogram plots for all regression models also suggest that normality is reasonable. The data are tested for homogeneity of variances using Levene's test and the assumption of homogeneity is satisfied. Examination of casewise diagnostics including Mahalanobis distance, Cook's distance, DfBeta values, and centered leverage values to determine multivariate outliers suggest there are no cases exerting undue influence on any of the regression models. Finally, the data are tested for mutlicollinearity to examine if two or more variables are highly correlated. A Variance Inflation Factor (VIF) of 10 is used as a critical value to determine if variables are highly correlated. Results show no evidence that multicollinearity is an issue.

\section{RESULTS}

\section{A. Descriptive Statics}

Table III shows the basic descriptive results for the dependent and independent variables. The results show that most of the teachers in elementary and middle schools are White with an average salary of $\$ 50 \mathrm{k}-\$ 60 \mathrm{k}$ per year and an average experience between 11-20 years. The average Climate Star rate is relatively high for both elementary $(\mathrm{M}=$ 3.96) and middle $(\mathrm{M}=4.01)$ schools, generally indicating good schools' environment and a positive perception by various education stakeholders about public schools in the state of Georgia. The average FESR rate is slightly higher for middle schools $(\mathrm{M}=3.20)$ than elementary schools $(\mathrm{M}=$ 2.83 ), indicating on average that the State spends more money per middle school student than elementary school student. However, the results do not tell us if spending per student is distributed differently based on demographics, socioeconomic status, or school environment and achievement. Student attendance and mobility score results are average on both scales for elementary and middle schools. On average, mobility rate is slightly higher for middle schools $(M=3.00)$ than elementary schools $(\mathrm{M}=2.77)$. The Subject Test Score Rate (STSR) for elementary schools ranges between 146-366 for Math and between 138-352 for ELA, whereas STSR for middle schools ranges between 126-341 for Math and between 144-333 for ELA.

TABLE III: DESCRIPTIVE STATISTICAL RESULT FOR ELEMENTARY AND MIDDLE SCHOOLS

\begin{tabular}{ccccccc}
\hline \hline \multirow{2}{*}{ Variable } & \multicolumn{3}{c}{ Elementary } & \multicolumn{3}{c}{ Middle } \\
\cline { 2 - 7 } & $\mathrm{M}$ & $\mathrm{SD}$ & $\mathrm{n}$ & $\mathrm{M}$ & $\mathrm{SD}$ & $\mathrm{n}$ \\
\hline Math Score & 238.46 & 40.26 & 1140 & 225.47 & 40.19 & 451 \\
ELA Score & 229.60 & 41.03 & 1140 & 223.92 & 36.44 & 451 \\
Salary & 2.14 & 0.54 & 1140 & 2.13 & 0.57 & 451 \\
Race & 3.20 & 1.12 & 1140 & 3.01 & 1.18 & 451 \\
Experience & 2.05 & 0.45 & 1140 & 1.98 & 0.45 & 451 \\
Climate & 3.96 & 0.90 & 1140 & 4.01 & 0.89 & 451 \\
FESR & 2.83 & 0.93 & 1140 & 3.20 & 0.97 & 451 \\
Attendance & 2.72 & 0.85 & 1140 & 2.67 & 1.04 & 451 \\
Mobility & 2.77 & 0.83 & 1140 & 3.00 & 0.78 & 451 \\
\hline \hline
\end{tabular}

Note: Dependent Variables: Math Score, ELA Score.

Independent Factors: Salary, Race, Experience, Climate, FESR, Attendance, Mobility

\section{B. Multivariate Linear Regression - Model 1}

Model 1 attempts to predict both the individual and combined main effects of teacher, school, and student factors on student subject test scores in Math and ELA. The relationships between teachers' individual factors (salary, race, and experience) and Math and ELA test scores for elementary schools are significant at 5\% confidence level ( $p$ $<0.05$, Table IV). 
TABLE IV: RELATIONSHIP COEFFICIENTS BETWEEN TEACHER FACTORS AND SCALED MATH AND ELA SCORES FOR ELEMENTARY AND MIDDLE SCHOOLS

\begin{tabular}{|c|c|c|c|c|c|c|c|c|c|c|}
\hline \multirow{3}{*}{ Variable } & \multicolumn{5}{|c|}{ MATH } & \multicolumn{5}{|c|}{ ELA } \\
\hline & \multicolumn{2}{|c|}{$\begin{array}{c}\text { Unstandard } \\
\text { Coeffes }\end{array}$} & \multirow{2}{*}{$\begin{array}{c}\begin{array}{c}\text { Standard } \\
\text { Coeffes }\end{array} \\
\text { Beta }\end{array}$} & \multirow[t]{2}{*}{$\mathrm{t}$} & \multirow[t]{2}{*}{ Sig. } & \multicolumn{2}{|c|}{$\begin{array}{l}\text { Unstandard } \\
\text { Coeffes }\end{array}$} & \multirow{2}{*}{$\begin{array}{c}\begin{array}{c}\text { Standard } \\
\text { Coeffes }\end{array} \\
\text { Beta }\end{array}$} & \multirow[t]{2}{*}{$\mathrm{t}$} & \multirow[t]{2}{*}{ Sig. } \\
\hline & B & $\begin{array}{l}\text { Std. } \\
\text { Err }\end{array}$ & & & & B & $\begin{array}{l}\text { Std. } \\
\text { Err }\end{array}$ & & & \\
\hline \multicolumn{11}{|c|}{ Elementary School } \\
\hline (Constant) & $127.6^{*}$ & 5.38 & & 23.98 & 0.000 & $115.8^{*}$ & 5.52 & & 20.90 & 0.000 \\
\hline Salary & $18.25^{*}$ & 1.86 & 0.243 & 9.943 & 0.000 & $19.87 *$ & 1.905 & 0.258 & 10.35 & 0.000 \\
\hline Race & $19.26^{*}$ & 0.86 & 0.535 & 22.54 & 0.000 & $18.36^{*}$ & 0.889 & 0.500 & 20.69 & 0.000 \\
\hline Experience & $5.010^{*}$ & 2.20 & 0.056 & 2.227 & 0.026 & $6.281^{*}$ & 2.335 & 0.068 & 2.690 & 0.007 \\
\hline \multicolumn{11}{|c|}{ Middle School } \\
\hline (Constant) & $108.1^{*}$ & 6.76 & & 16.00 & 0.000 & $121.3^{*}$ & 6.530 & & 18.58 & 0.000 \\
\hline Salary & $24.26^{*}$ & 2.39 & 0.343 & 10.11 & 0.000 & $24.99 *$ & 2.316 & 0.390 & 10.79 & 0.000 \\
\hline Race & $20.20 *$ & 1.13 & 0.595 & 17.87 & 0.000 & $15.96^{*}$ & 1.091 & 0.519 & 14.63 & 0.000 \\
\hline Experience & $2.407 *$ & 3.12 & 0.027 & 0.770 & 0.442 & $0.538 *$ & 3.019 & 0.007 & 0.178 & 0.859 \\
\hline
\end{tabular}

Note: *p $<0.05$

However, the teachers' factors by themselves cannot explain very well the variability in student test scores $(39 \%$ for Math and $36.7 \%$ for ELA, Table VI).

For middle schools, only salary and race factors are significant at 5\% confidence level. Teacher experience is not significant $(p=0.859$, Table IV). Furthermore, teacher factors fare better in explaining the variation in student test scores (53.8\% for Math and $47.5 \%$ for ELA, Table VI).

The relationships between schools' individual factors (climate and FESR) and Math and ELA test scores for elementary schools are significant at 5\% confidence level (p $<0.05$, Table V).
School factors explain the variability in student test scores better than teachers' factors $(52.2 \%$ for Math and $49.1 \%$ for ELA, Table VI). For middle schools, all school factors are significant at 5\% confidence level and substantially explain the variability in student test scores $(64.1 \%$ for Math and $60.5 \%$ for ELA, Table VI).

Table VII show that students' individual factors (attendance and mobility) do affect Math and ELA test scores for elementary and middle schools at 5\% confidence level. Students' factors can moderately explain the variability in student test scores for both elementary (41.8\% for Math and $41.3 \%$ for ELA, Table VI) and middle schools (51.8\% for Math and $47.1 \%$ for ELA, Table VI).

TABLE V: RELATIONSHIP COEFFICIENTS BETWEEN SCHOOL FACTORS AND SCALED MATH AND ELA SCORES For ELEMENTARY AND MidDLE SCHOOLS

\begin{tabular}{|c|c|c|c|c|c|c|c|c|c|c|}
\hline \multirow{3}{*}{ Variable } & \multicolumn{5}{|c|}{ MATH } & \multicolumn{5}{|c|}{ ELA } \\
\hline & \multicolumn{2}{|c|}{$\begin{array}{l}\text { Unstandard } \\
\text { Coeffes }\end{array}$} & \multirow{2}{*}{$\begin{array}{c}\text { Standard } \\
\text { Coeffes }\end{array}$} & \multirow[t]{2}{*}{$\mathrm{t}$} & \multirow[t]{2}{*}{ Sig. } & \multicolumn{2}{|c|}{$\begin{array}{l}\text { Unstandard } \\
\text { Coeffes }\end{array}$} & \multirow{2}{*}{$\begin{array}{c}\text { Standard } \\
\text { Coeffes }\end{array}$} & \multirow[t]{2}{*}{$\mathrm{t}$} & \multirow[t]{2}{*}{ Sig. } \\
\hline & B & $\begin{array}{l}\text { Std. } \\
\text { Err }\end{array}$ & & & & B & $\begin{array}{l}\text { Std. } \\
\text { Err }\end{array}$ & & & \\
\hline \multicolumn{11}{|c|}{ Elementary School } \\
\hline (Constant) & $117.2^{*}$ & 3.94 & & 29.72 & 0.000 & $110.4 *$ & 4.15 & & 26.62 & 0.000 \\
\hline Climate & $13.32 *$ & 0.99 & 0.296 & 13.42 & 0.000 & $12.85 *$ & 1.04 & 0.280 & 12.30 & 0.000 \\
\hline FESR & $24.17 *$ & 0.95 & 0.558 & 25.26 & 0.000 & $24.11 *$ & 1.00 & 0.546 & 23.96 & 0.000 \\
\hline \multicolumn{11}{|c|}{ Middle School } \\
\hline (Constant) & $89.28^{*}$ & 5.44 & & 16.38 & 0.000 & $103.9 *$ & 5.18 & & 20.05 & 0.000 \\
\hline Climate & $14.18^{*}$ & 1.48 & 0.313 & 9.541 & 0.000 & $12.49 *$ & 1.41 & 0.304 & 8.83 & 0.000 \\
\hline FESR & $24.75^{*}$ & 1.36 & 0.596 & 18.20 & 0.000 & $21.81 *$ & 1.29 & 0.579 & 16.86 & 0.000 \\
\hline
\end{tabular}

TABLE VII: RELATIONSHIP COEFFICIENTS BETWEEN STUDENT FACTORS AND SCALED MATH AND ELA SCORES FOR ELEMENTARY AND MIDDLE SCHOOLS

\begin{tabular}{|c|c|c|c|c|c|c|c|c|c|c|}
\hline \multirow{3}{*}{ Variable } & \multicolumn{5}{|c|}{ MATH } & \multicolumn{5}{|c|}{ ELA } \\
\hline & \multicolumn{2}{|c|}{$\begin{array}{c}\text { Unstandard } \\
\text { Coeffes }\end{array}$} & \multirow{2}{*}{$\begin{array}{c}\text { Standard } \\
\text { Coeffes } \\
\text { Beta }\end{array}$} & \multirow[t]{2}{*}{$\mathrm{t}$} & \multirow[t]{2}{*}{ Sig. } & \multicolumn{2}{|c|}{$\begin{array}{l}\text { Unstandard } \\
\text { Coeffes }\end{array}$} & \multirow{2}{*}{$\begin{array}{c}\text { Standard } \\
\text { Coeffes } \\
\text { Beta }\end{array}$} & \multirow[t]{2}{*}{$\mathrm{t}$} & \multirow[t]{2}{*}{ Sig. } \\
\hline & B & $\begin{array}{l}\text { Std. } \\
\text { Err }\end{array}$ & & & & B & $\begin{array}{l}\text { Std. } \\
\text { Err }\end{array}$ & & & \\
\hline \multicolumn{11}{|c|}{ Elementary School } \\
\hline (Constant) & $138.6^{*}$ & 3.69 & & 37.55 & 0.000 & $128.9^{*}$ & 3.77 & & 34.14 & 0.000 \\
\hline Mobility & $25.49 *$ & 1.18 & 0.525 & 21.46 & 0.000 & $26.32 *$ & 1.21 & 0.531 & 21.65 & 0.000 \\
\hline Attendance & $10.77 *$ & 1.15 & 0.228 & 9.335 & 0.000 & $10.22 *$ & 1.18 & 0.212 & 8.656 & 0.000 \\
\hline \multicolumn{11}{|l|}{ Middle School } \\
\hline (Constant) & $109.2 *$ & 5.58 & & 19.55 & 0.000 & $121.6^{*}$ & 5.30 & & 22.93 & 0.000 \\
\hline Mobility & $34.82 *$ & 1.73 & 0.681 & 20.07 & 0.000 & $28.76^{*}$ & 1.64 & 0.620 & 17.45 & 0.000 \\
\hline Attendance & $4.39 *$ & 1.30 & 0.114 & 3.356 & 0.001 & $5.96^{*}$ & 1.24 & 0.170 & 4.796 & 0.000 \\
\hline
\end{tabular}

Note: $* \mathrm{p}<0.05$ 
TABLE VII: INDIVIDUAL AND COMBINED LINEAR REGRESSION MODELS: SUMMARY OF THE RELATIONSHIP BETWEEN TEACHER, SCHOOL AND STUDENT FACTORS AND SCALED MATH AND ELA SCORES

\begin{tabular}{ccccc}
\hline \hline Regression Model & $\mathrm{R}$ & $\mathrm{R}$ Square & $\begin{array}{c}\text { Adjusted R } \\
\text { Square }\end{array}$ & $\begin{array}{c}\text { Std. Err of the } \\
\text { Estimate }\end{array}$ \\
\hline Elementary Math Scores & & & & \\
Teacher Factors & 0.624 & 0.390 & 0.388 & 31.478 \\
School Factors & 0.722 & 0.522 & 0.521 & 27.863 \\
Student Factors & 0.647 & 0.418 & 0.417 & 30.716 \\
Combined Factors & 0.836 & 0.698 & 0.697 & 22.176 \\
Elementary ELA Scores & & & & \\
Teacher Factors & 0.606 & 0.367 & 0.366 & 32.660 \\
School Factors & 0.700 & 0.491 & 0.490 & 29.307 \\
Student Factors & 0.643 & 0.413 & 0.412 & 31.436 \\
Combined Factors & 0.820 & 0.672 & 0.670 & 23.582 \\
Middle Math Scores & & & & \\
Teacher Factors & 0.733 & 0.538 & 0.535 & 27.301 \\
School Factors & 0.801 & 0.641 & 0.639 & 24.139 \\
Student Factors & 0.720 & 0.518 & 0.516 & 27.905 \\
Combined Factors & 0.890 & 0.793 & 0.789 & 18.445 \\
Middle ELA Scores & & & & \\
Teacher Factors & 0.689 & 0.475 & 0.471 & 26.368 \\
School Factors & 0.778 & 0.605 & 0.603 & 22.958 \\
Student Factors & 0.686 & 0.471 & 0.468 & 26.502 \\
Combined Factors & 0.861 & 0.742 & 0.738 & 18.663 \\
\hline \hline
\end{tabular}

TABLE VIII: RELATIONSHIP COEFFICIENTS BETWEEN STUDENT FACTORS AND SCALED MATH AND ELA SCORES FOR ELEMENTARY AND MIDDLE SCHOOLS

\begin{tabular}{|c|c|c|c|c|c|c|c|c|c|c|}
\hline \multirow{3}{*}{ Variable } & \multicolumn{5}{|c|}{ MATH } & \multicolumn{5}{|c|}{ ELA } \\
\hline & \multicolumn{2}{|c|}{$\begin{array}{c}\text { Unstandard } \\
\text { Coeffes }\end{array}$} & \multirow{2}{*}{$\begin{array}{c}\begin{array}{c}\text { Standard } \\
\text { Coeffes }\end{array} \\
\text { Beta }\end{array}$} & \multirow[t]{2}{*}{$\mathrm{t}$} & \multirow[t]{2}{*}{ Sig. } & \multicolumn{2}{|c|}{$\begin{array}{l}\text { Unstandard } \\
\text { Coeffes }\end{array}$} & \multirow{2}{*}{$\begin{array}{c}\begin{array}{c}\text { Standard } \\
\text { Coeffes }\end{array} \\
\text { Beta }\end{array}$} & \multirow[t]{2}{*}{$\mathrm{t}$} & \multirow[t]{2}{*}{ Sig. } \\
\hline & B & $\begin{array}{l}\text { Std. } \\
\text { Err }\end{array}$ & & & & B & $\begin{array}{c}\text { Std. } \\
\text { Err }\end{array}$ & & & \\
\hline \multicolumn{11}{|c|}{ Elementary School } \\
\hline (Constant) & $138.6^{*}$ & 3.69 & & 37.55 & 0.000 & $128.9^{*}$ & 3.77 & & 34.14 & 0.000 \\
\hline Mobility & $25.49 *$ & 1.18 & 0.525 & 21.46 & 0.000 & $26.32^{*}$ & 1.21 & 0.531 & 21.65 & 0.000 \\
\hline Attendance & $10.77 *$ & 1.15 & 0.228 & 9.335 & 0.000 & $10.22^{*}$ & 1.18 & 0.212 & 8.656 & 0.000 \\
\hline \multicolumn{11}{|l|}{ Middle Schhol } \\
\hline (Constant) & $109.2^{*}$ & 5.58 & & 19.55 & 0.000 & $121.6^{*}$ & 5.30 & & 22.93 & 0.000 \\
\hline Mobility & $34.82 *$ & 1.73 & 0.681 & 20.07 & 0.000 & $28.76^{*}$ & 1.64 & 0.620 & 17.45 & 0.000 \\
\hline Attendance & $4.39 *$ & 1.30 & 0.114 & 3.356 & 0.000 & $5.96^{*}$ & 1.24 & 0.170 & 4.796 & 0.000 \\
\hline
\end{tabular}

Note: ${ }^{*} \mathrm{p}<0.5$.

TABLE IX: RELATIONSHIP COEFFICIENTS BETWEEN TEACHER, SCHOOL AND STUDENT FACTORS AND SCALED MATH AND ELA SCORES FOR ELEMENTARY AND MIDDLE SCHOOLS IN A COMNIBED LINEAR REGRESSION MODEL

\begin{tabular}{|c|c|c|c|c|c|c|c|c|c|c|}
\hline \multirow{3}{*}{ Variable } & \multicolumn{5}{|c|}{ MATH } & \multicolumn{5}{|c|}{ ELA } \\
\hline & \multicolumn{2}{|c|}{$\begin{array}{c}\text { Unstandard } \\
\text { Coeffes }\end{array}$} & \multirow{2}{*}{$\begin{array}{c}\begin{array}{c}\text { Standard } \\
\text { Coeffes }\end{array} \\
\text { Beta }\end{array}$} & \multirow[t]{2}{*}{$\mathrm{t}$} & \multirow[t]{2}{*}{ Sig. } & \multicolumn{2}{|c|}{$\begin{array}{c}\text { Unstandard } \\
\text { Coeffes }\end{array}$} & \multirow{2}{*}{$\begin{array}{c}\begin{array}{c}\text { Standard } \\
\text { Coeffes }\end{array} \\
\text { Beta }\end{array}$} & \multirow[t]{2}{*}{$\mathrm{t}$} & \multirow[t]{2}{*}{ Sig. } \\
\hline & $\mathrm{B}$ & $\begin{array}{l}\text { Std. } \\
\text { Err }\end{array}$ & & & & $\mathrm{B}$ & $\begin{array}{l}\text { Std. } \\
\text { Err }\end{array}$ & & & \\
\hline \multicolumn{11}{|c|}{ Elementary School } \\
\hline (Constant) & $60.26^{*}$ & 4.52 & & 13.33 & 0.000 & $48.89^{*}$ & 4.80 & & 10.17 & 0.000 \\
\hline Mobility & $12.14^{*}$ & 0.97 & 0.250 & 12.47 & 0.000 & $13.51^{*}$ & 1.03 & 0.273 & 13.05 & 0.000 \\
\hline Climate & $7.824 *$ & 0.84 & 0.174 & 9.315 & 0.000 & $7.543^{*}$ & 0.89 & 0.165 & 8.444 & 0.000 \\
\hline FESR & $14.31 *$ & 0.87 & 0.330 & 16.43 & 0.000 & $14.29 *$ & 0.92 & 0.324 & 15.44 & 0.000 \\
\hline Salary & $13.58 *$ & 1.30 & 0.181 & 10.40 & 0.000 & $15.07 *$ & 1.38 & 0.197 & 10.85 & 0.000 \\
\hline Race & $6.977^{*}$ & 0.73 & 0.194 & 9.446 & 0.000 & $5.793^{*}$ & 0.78 & 0.158 & 7.376 & 0.000 \\
\hline Experience & $-0.28 *$ & 1.60 & -0.003 & -0.17 & 0.860 & $0.733^{*}$ & 1.70 & 0.008 & 0.429 & 0.668 \\
\hline Attendance & $8.226^{*}$ & 0.85 & 0.174 & 9.595 & 0.000 & $7.631^{*}$ & 0.91 & 0.159 & 8.370 & 0.000 \\
\hline \multicolumn{11}{|l|}{ Middle School } \\
\hline (Constant) & $48.37^{*}$ & 5.47 & & 8.828 & 0.000 & $65.96^{*}$ & 5.54 & & 11.89 & 0.000 \\
\hline Mobility & $14.18^{*}$ & 1.48 & 0.276 & 9.567 & 0.000 & $11.23^{*}$ & 1.50 & 0.241 & 7.491 & 0.000 \\
\hline Climate & $7.520 *$ & 1.21 & 0.166 & 6.180 & 0.000 & $6.750^{*}$ & 1.23 & 0.164 & 5.482 & 0.000 \\
\hline FESR & $13.69 *$ & 1.24 & 0.330 & 11.03 & 0.000 & $13.15^{*}$ & 1.25 & 0.350 & 10.47 & 0.000 \\
\hline Salary & $14.34 *$ & 1.69 & 0.202 & 8.487 & 0.000 & $15.32^{*}$ & 1.71 & 0.238 & 8.960 & 0.000 \\
\hline Race & $7.190^{*}$ & 1.02 & 0.211 & 7.033 & 0.000 & $4.582^{*}$ & 1.03 & 0.148 & 4.429 & 0.000 \\
\hline Experience & $0.708^{*}$ & 2.14 & 0.008 & 0.331 & 0.741 & $-0.59^{*}$ & 2.16 & -0.007 & -0.27 & 0.784 \\
\hline Attendance & $2.602 *$ & 0.94 & 0.067 & 2.767 & 0.000 & $3.663^{*}$ & 0.95 & 0.104 & 3.850 & 0.000 \\
\hline
\end{tabular}

Note: ${ }^{*} \mathrm{p}<0.5$.

Table VIII shows that collectively there is a strong relationship between all independent variables (teacher, school, and student) and student test scores in Math and ELA. The only exceptions are for teacher experience in elementary ( $p=0.860$ for Math and $p=0.688$ for ELA) and middle ( $p=$ 0.741 for Math and $p=0.784$ for ELA) schools. The combined main effects of all independent variables can significantly explain the variation in student test scores for both elementary (69.8\% for Math and $67.2 \%$ for ELA, Table VI) and middle schools (79.3\% for Math and $74.2 \%$ for ELA, Table VI). 


\section{Multivariate Linear Regression-Model 2}

Model 2 attempts to predict the interaction effects within teacher, school, and student factors on student test scores in Math and ELA. For elementary schools, all individual factors are significant at the 5\% confidence level except for teacher experience ( $p=0.926$ for Math and $p=0.53$ for ELA, Table IX). The interaction within student factors (attendance and mobility) is not significant for Math ( $p=0.183$, Table IX) but is significant for ELA $(p<0.05$, Table IX). The interactions within school factors (climate and FESR) and within teacher factors (salary, race, and experience) are not significant for Math ( $\mathrm{p}=0.951$, Table IX) and ELA ( $\mathrm{p}=0.649$, Table IX). The interactions within independent variables (teacher, school, and student) do not add further explanation to the variability in the student Math test scores and are not significant (Tables IX and $\mathrm{X}$ ). However, the interaction effects within student factors are significant for ELA test scores $(\mathrm{p}<0.05$, Table IX), but added a minimal explanation to the test score variability (Table $\mathrm{X})$.

TABLE X: COEFFICIENTS OF INTERACTION EFFECTS WITHIN TEACHER, SCHOOL AND STUDENT FACTORS ON SCALED MATH AND ELA SCORES FOR

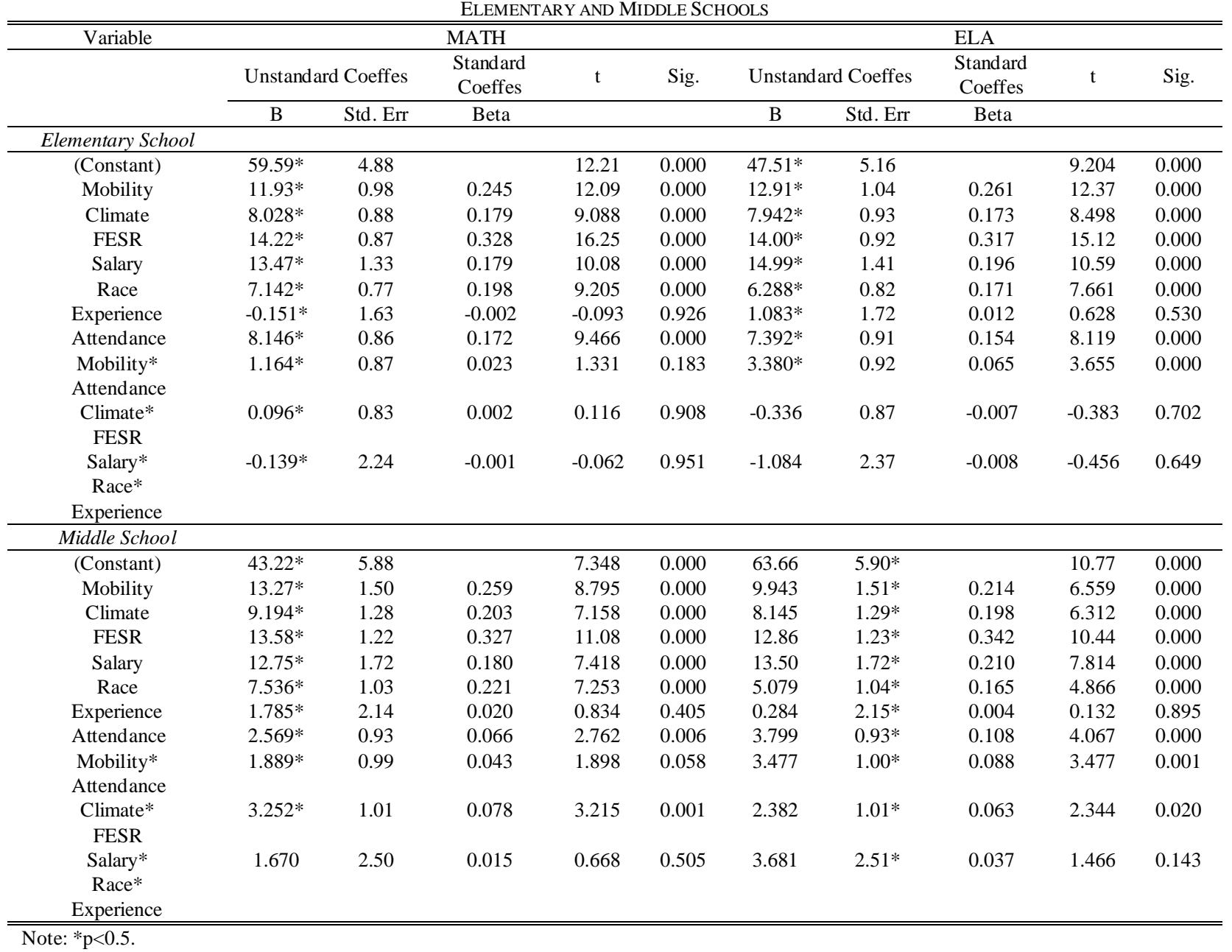

For middle schools, all individual factors are significant at the $5 \%$ confidence level except for teacher experience $(p=$ 0.405 for Math and $p=0.895$ for ELA, Table IX). The interaction within student factors (attendance and mobility) is not significant for Math ( $p=0.058$, Table IX) but is significant for ELA ( $p=0.001$, Table IX). The interaction within school factors (climate and FESR) is significant for Math ( $p=0.001$, Table IX) and ELA ( $p=0.020$, Table IX), while the interactions within teacher factors (salary, race, and experience) are not significant for Math and ELA. The interactions within independent variables (teacher, school, and student) add a minimal explanation to the variability in Math and ELA test scores (Table X).

\section{Multivariate Linear Regression - Model 3}

Model 3 attempts to predict the interaction effects between the three independent variables (teacher, school, and student) on student test scores in Math and ELA. For elementary schools, all individual factors are significant at the 5\% confidence level except for teacher experience $(p=0.881$ for Math and $p=0.386$ for ELA, Table XI). The interaction effects between teacher and student factors are not significant for Math $(p=0.581$, Table XI) and ELA $(p=0.214$, Table $\mathrm{XI})$. The interaction effects between teacher and school factors are significant for Math $(p=0.020$, Table XI) but not significant for ELA $(p=0.058$, Table XI). The interaction effects between school and student factors are not significant for both Math ( $p=0.322$, Table XI) and ELA ( $p=0.771$, Table XI). The interactions between the three independent variables add a minimal explanation to the variability in the Math and ELA test scores. 
TABLE XI: MAIN AND INTERACTION EFFECTS REGRESSION MODELS: SUMMARY OF THE RELATIONSHIP BETWEEN TEACHER, SCHOOL AND STUDENT FACTORS AND SCALED MATH AND ELA SCORES

\begin{tabular}{|c|c|c|c|c|c|c|c|}
\hline Regression Model & $\mathrm{R}$ & $\begin{array}{c}\mathrm{R} \\
\text { Square }\end{array}$ & $\begin{array}{c}\text { Adjusted } \\
\text { R } \\
\text { Square }\end{array}$ & $\begin{array}{l}\text { Std. Err } \\
\text { of the } \\
\text { Estimate }\end{array}$ & $\begin{array}{c}\text { R } \\
\text { Square } \\
\text { Change }\end{array}$ & $\begin{array}{c}\text { F } \\
\text { Change }\end{array}$ & $\begin{array}{c}\text { Sig. F } \\
\text { Change }\end{array}$ \\
\hline \multicolumn{8}{|l|}{ Elementary Math } \\
\hline Main Effects & 0.836 & 0.698 & 0.697 & 22.176 & 0.698 & $374.5^{*}$ & 0.000 \\
\hline Interactions Within & 0.836 & 0.699 & 0.696 & 22.188 & 0.000 & $0.608 *$ & 0.610 \\
\hline Interactions Between & 0.837 & 0.700 & 0.698 & 22.139 & 0.002 & 2.29 & 0.077 \\
\hline \multicolumn{8}{|l|}{ Elementary ELA } \\
\hline Main Effects & 0.820 & 0.672 & 0.670 & 23.582 & 0.672 & $330.7 *$ & 0.000 \\
\hline Interactions Within & 0.822 & 0.676 & 0.673 & 23.473 & 0.004 & $4.51 *$ & 0.004 \\
\hline Interactions Between & 0.821 & 0.674 & 0.671 & 23.543 & 0.002 & 2.26 & 0.079 \\
\hline \multicolumn{8}{|l|}{ Middle Math } \\
\hline Main Effects & 0.890 & 0.793 & 0.789 & 18.445 & 0.793 & $241.8 *$ & 0.000 \\
\hline Interactions Within & 0.895 & 0.801 & 0.796 & 18.146 & 0.008 & $5.90 *$ & 0.001 \\
\hline Interactions Between & 0.892 & 0.795 & 0.790 & 18.400 & 0.002 & 1.72 & 0.161 \\
\hline \multicolumn{8}{|l|}{ Middle ELA } \\
\hline Main Effects & 0.861 & 0.742 & 0.738 & 18.663 & 0.742 & $181.8 *$ & 0.000 \\
\hline Interactions Within & 0.895 & 0.755 & 0.750 & 18.229 & 0.014 & $8.11 *$ & 0.000 \\
\hline Interactions Between & 0.866 & 0.749 & 0.744 & 18.449 & 0.008 & $4.44 *$ & 0.004 \\
\hline
\end{tabular}

For middle schools, all individual factors are significant at the 5\% confidence level except for teacher experience ( $p=$ 0.312 for Math and $p=0.745$ for ELA, Table XI). The interaction between teacher and student factors is not significant for both Math $(p=0.596$, Table XI) and ELA $(p=$ 0.573 , Table XI). The interaction between teacher and school factors is also not significant for both Math $(p=0.321$, Table $\mathrm{XI})$ and ELA $(p=0.073$, Table XI). However, the interaction between school and student factors is significant for Math $(p$ $=0.049$, Table XI $)$ and ELA $(p=0.02$, Table XI). The interactions between the three independent variables add a minimal explanation to the variability in the student Math and ELA test scores

\section{DISCUSSION}

To better understand the significant antecedents of student test scores in Math and ELA in public schools, a holistic approach that includes all probable factors and their interactions must be considered. While prior research focused on one or two factors at a time, this study includes three main independent variables and seven factors associated with them.

\section{A. Teacher Factors}

Results show that teacher salary has a statistically significant effect on Math and ELA test scores for elementary schools, while controlling other variables. A unit increase in teacher salary (i.e., $\$ 10 \mathrm{k} / \mathrm{year}$ ) can improve Math test scores by 18 points (8\%) and ELA test scores by 20 points $(9 \%)$. The impact is more significant for middle schools where a unit increase in teacher salary can improve Math test scores by 24 points (11\%) and ELA test scores by 25 points (13\%). One can argue that middle school teachers are more likely to be motivated to perform better and improve student test scores than elementary school teachers when they are compensated properly. The relationship between teacher wages and student outcomes has been debated amongst researchers and policymakers for decades. Proponents of a merit pay structure argue that such system has the potential to improve student test scores by motivating teachers to do better job in their classrooms or by competitively recruiting and retaining highly qualified teachers (Dee \& Wyckoff, 2015). On the other hand, opponents of merit pay system cited other research where the impact of teacher wages on student test scores was negligent (Pham et al., 2020; Springer et al., 2014; (Fryer, 2013). The cited research claimed that the process of identifying efficacy in teaching is not reliable and cannot simply predict teacher quality, performance, or behavior based on a merit pay structure.

The relationship between teacher race and student test scores in Math and ELA is statistically significant, while controlling other variables. For elementary schools, a unit increase in teacher race (i.e., $25 \%$ increase in White teacher percentage) can improve Math test scores by 19 points (9\%) and ELA test scores by 18 points ( $8 \%$ ). For middle schools, a unit increase in teacher race can improve Math test scores by 20 points (9\%) and ELA test scores by 16 points $(8 \%)$. However, the causality of a better student performance with a higher percentage of White teachers cannot be merely derived from these results without looking at other factors.

In fact, a further review of the data from the state of Georgia tells us that minority teachers are more concentrated in Title I schools where school environment, resources, and student factors have negative impact on test scores. We know that minority teachers are not well represented in American public schools (Yarnel \& Bohrnstedt, 2018; Partelow et al., 2017). Prior research has shown that the racial disparity in student test scores can improve by recruiting more minority teachers in schools (Savasci \& Tomul, 2013). Student Math and Reading test scores has been shown to be positively impacted when students were matched with race-congruent teachers (Clotfelter et al., 2005; Partelow et al., 2017). These teachers can act integrators of diverse cultures, role models, and advocates for students with the same race or ethnicity. 
TABLE XII: COEFFICIENTS OF INTERACTION EFFECTS BETWEEN TEACHER, SCHOOL AND STUDENT FACTORS ON SCALED MATH AND ELA SCORES FOR ELEMENTARY AND MIDDLE SCHOOLS

\begin{tabular}{|c|c|c|c|c|c|c|c|c|c|c|}
\hline \multirow[t]{3}{*}{ Variable } & \multicolumn{5}{|c|}{ MATH } & \multicolumn{5}{|c|}{ ELA } \\
\hline & \multicolumn{2}{|c|}{$\begin{array}{c}\text { Unstandard } \\
\text { Coeffes }\end{array}$} & \multirow{2}{*}{$\begin{array}{c}\begin{array}{c}\text { Standard } \\
\text { Coeffes }\end{array} \\
\text { Beta }\end{array}$} & \multirow[t]{2}{*}{$\mathrm{t}$} & \multirow[t]{2}{*}{ Sig. } & \multicolumn{2}{|c|}{$\begin{array}{c}\text { Unstandard } \\
\text { Coeffes }\end{array}$} & \multirow{2}{*}{$\begin{array}{c}\text { Standard } \\
\text { Coeffes }\end{array}$} & \multirow[t]{2}{*}{$\mathrm{t}$} & \multirow[t]{2}{*}{ Sig. } \\
\hline & B & $\begin{array}{l}\text { Std. } \\
\text { Err }\end{array}$ & & & & B & $\begin{array}{l}\text { Std. } \\
\text { Err }\end{array}$ & & & \\
\hline \multicolumn{11}{|c|}{ Elementary School } \\
\hline (Constant) & $57.64 *$ & 4.93 & & 11.68 & 0.000 & $45.74 *$ & 5.22 & & 8.762 & 0.000 \\
\hline Mobility & $11.86^{*}$ & 0.98 & 0.244 & 12.03 & 0.000 & $12.86^{*}$ & 1.04 & 0.260 & 12.33 & 0.000 \\
\hline Climate & $8.179 *$ & 0.88 & 0.182 & 9.251 & 0.000 & $8.072 *$ & 0.93 & 0.176 & 8.627 & 0.000 \\
\hline FESR & $14.44 *$ & 0.87 & 0.333 & 16.42 & 0.000 & $14.15^{*}$ & 0.93 & 0.321 & 15.21 & 0.000 \\
\hline Salary & $13.61 *$ & 1.33 & 0.181 & 10.17 & 0.000 & $15.13^{*}$ & 1.41 & 0.197 & 10.68 & 0.000 \\
\hline Race & $7.012 *$ & 0.77 & 0.195 & 9.027 & 0.000 & $6.140^{*}$ & 0.82 & 0.167 & 7.468 & 0.000 \\
\hline Experience & $0.245^{*}$ & 1.63 & 0.003 & 0.150 & 0.881 & 1.500 & 1.73 & 0.016 & 0.867 & 0.386 \\
\hline Attendance & 8. $277^{*}$ & 0.87 & 0.175 & 9.510 & 0.000 & $7.512 *$ & 0.92 & 0.156 & 8.155 & 0.000 \\
\hline $\begin{array}{c}\text { Teacher* } \\
\text { Student }\end{array}$ & $-1.72 *$ & 3.13 & -0.011 & -0.55 & 0.581 & $-4.11^{*}$ & 3.31 & -0.026 & -1.24 & 0.214 \\
\hline $\begin{array}{c}\text { Teacher* } \\
\text { School }\end{array}$ & $-5.25^{*}$ & 2.25 & -0.042 & -2.33 & 0.020 & -4.51 & 2.38 & -0.035 & -1.89 & 0.058 \\
\hline $\begin{array}{l}\text { School }^{*} \\
\text { Student }\end{array}$ & $0.890 *$ & 0.89 & 0.020 & 0.990 & 0.322 & 0.277 & 0.95 & 0.006 & 0.291 & 0.771 \\
\hline \multicolumn{11}{|l|}{ Middle School } \\
\hline (Constant) & $47.89^{*}$ & 5.68 & & 8.427 & 0.000 & $65.77^{*}$ & 5.69 & & 11.54 & 0.000 \\
\hline Mobility & $14.06^{*}$ & 1.48 & 0.274 & 9.443 & 0.000 & $11.11^{*}$ & 1.49 & 0.239 & 7.445 & 0.000 \\
\hline Climate & $7.746^{*}$ & 1.22 & 0.171 & 6.325 & 0.000 & $7.046^{*}$ & 1.22 & 0.171 & 5.738 & 0.000 \\
\hline FESR & $13.59^{*}$ & 1.24 & 0.328 & 10.96 & 0.000 & $13.01 *$ & 1.24 & 0.346 & 10.46 & 0.000 \\
\hline Salary & $13.75^{*}$ & 1.73 & 0.194 & 7.947 & 0.000 & $14.23^{*}$ & 1.73 & 0.221 & 8.206 & 0.000 \\
\hline Race & $7.230 *$ & 1.03 & 0.212 & 6.956 & 0.000 & $4.580^{*}$ & 1.04 & 0.148 & 4.395 & 0.000 \\
\hline Experience & 0.674 & 2.15 & 0.008 & 0.312 & 0.755 & -0.70 & 2.16 & -0.009 & -0.32 & 0.745 \\
\hline Attendance & $3.020 *$ & 0.95 & 0.078 & 3.158 & 0.002 & $4.329 *$ & 0.95 & 0.123 & 4.516 & 0.000 \\
\hline $\begin{array}{c}\text { Teacher* } \\
\text { Student }\end{array}$ & -0.99 & 1.88 & -0.014 & -0.53 & 0.596 & -1.06 & 1.88 & -0.016 & -0.56 & 0.573 \\
\hline $\begin{array}{l}\text { Teacher* } \\
\text { School }\end{array}$ & 0.225 & 0.22 & 0.026 & 0.994 & 0.321 & 0.408 & 0.22 & 0.053 & 1.798 & 0.073 \\
\hline $\begin{array}{l}\text { School* } \\
\text { Student }\end{array}$ & 1.150 & 0.58 & 0.045 & 1.970 & 0.050 & 1.822 & 0.58 & 0.078 & 3.112 & 0.002 \\
\hline
\end{tabular}

Teacher experience has a statistically significant effect on Math and ELA test scores for elementary schools, while controlling other variables. However, a unit increase in teacher experience (i.e., nearly 15 years) can improve Math test scores by only 5 points $(2 \%)$ and ELA test scores by 6 points $(3 \%)$. The impact of teacher experience is not statistically significant for middle schools. These findings are consistent with the findings by Dial (2008), where the effect of teacher experience on overall student test scores in communication arts and Math sections of the Missouri Assessment Program (MAP) was investigated. Hanushek (1998) concluded that elementary school teachers with more years of experience had a modest positive effect on student test score (Dial, 2008). However, secondary school teachers with more years of experience had no or little effect on student test scores up to 20 years, when it then negatively affected test scores. Some researchers have argued that sometimes "more is not necessarily better" where the impact of more experienced teachers on student test scores starts to fade away after 5 years (Weaver, 2019; Ladd, 2008; Clotfelter, et al., 2007). Other researchers stated that earlycareer teachers up to 3 years of experience are more likely to teach in Title I schools where teacher quality and productivity is a challenge (Gershenson, 2016). Therefore, a deep dive into the distribution pattern of inexperience teachers is needed in order to fully understand the impact of teacher experience on student test scores.

\section{B. School Factors}

The climate star rate has a statistically significant effect on Math and ELA test scores, while controlling other variables. For elementary schools, a unit increase in climate star rate can improve Math test scores by 13 points (6\%) and ELA test scores by 13 points $(6 \%)$. The impact is similar for middle schools where a unit increase in climate star rate can improve Math test scores by 14 points (7\%) and ELA test scores by 12 points $(6 \%)$. The FESR rate is significantly more impactful than the climate star rate on the Math and ELA test scores. For elementary schools, a unit increase in FESR rate can improve Math test scores by 24 points (11\%) and ELA test scores by 24 points $(11 \%)$. The impact is similar for middle schools where a unit increase in FESR rate can improve Math test scores by 25 points $(12 \%)$ and ELA test scores by 22 points (12\%). School climate factor is multifaceted since it includes quantitively measured attributes such as student record, teacher record, safe environment, substance free, as well as perceived attributes such as teacher and parent surveys. According to some researchers it is one of the leading contributors in explaining student learning and test scores (Maxwell, et al., 2017; Dulay \& Karadağ, 2017; Maxwell, 2016) as well as student emotional and behavioral achievements (Newland, et al., 2019). Furthermore, there is overwhelming evidence in research that per pupil expenditure (PPE) is positively correlated to student learning and standardized test scores (Jackson et al., 2016; Sun, 2014; Hanushek \& Woessmann, 2017; Ostrander, 2015). Increase 
in PPE is especially critical for low-income children and Title 1 schools since research has shown such an increase will reduce achievement gaps between low-income students and their peers and yield higher graduation rate, higher earnings, and reduction in adult poverty (Cooper, 2017; Jackson et al., 2016).

\section{Student Factors}

The mobility rate has a high positive correlation with the Math and ELA test scores, while controlling other variables. For elementary schools, a unit increase in the mobility rate scale (less mobile) can improve Math test scores by 25 points $(11 \%)$ and ELA test scores by 26 points $(12 \%)$. The impact was higher for middle schools where a unit increase in the mobility rate scale can improve Math test scores by 34 points (16\%) and ELA test scores by 29 points (15\%). This finding suggests that middle school students may have harder time to cope with a new school than elementary school students. The content areas in middle school are more structured and academically challenging than elementary school subjects. Hence, adjustment period to a new school environment can be longer for middle school students. In addition, a change in a school can create significant social challenges for middle school students such as leaving old friends behind and trying to create new ones. This finding is consistent with the general consensus in literature that more mobility is associated with negative outcomes on academic achievement (Sparks, 2016(Rhodes, 2005). Other researchers have argued that mobility by itself is not the main effect for an unsatisfactory student's outcome but rather a combination of other factors. For example, highly mobile students tend to come from lowincome families where parents did not attain higher education and did not have stable jobs (Donnelly \& Gamsu, 2018; Welsh, 2017).

The attendance rate was less impactful than the mobility star rate on the Math and ELA test scores. For elementary schools, a unit increase in attendance rate can improve Math test scores by 11 points $(5 \%)$ and ELA test scores by 10 points (5\%), while controlling other variables. The impact is much less for middle schools where a unit increase in attendance rate can improve Math test scores by only 4 points $(2 \%)$ and ELA test scores by 6 points $(3 \%)$. There is overwhelming evidence in the literature pointing to a positive impact of attendance rate on student test scores (McGahee, 2019; Gottfried, 2010). The NCLB Act of 2001 dictates states, school districts, and individual schools to report student attendance as part of the Adequate Yearly Progress (AYP) requirements; hence emphasizing its impact on student and school performance (No Child Left Behind Act of 2001, 2002).

\section{Combined Effect of Teacher, School, and Student Factors}

The aggregate main effect of teacher, school, and student factors shows statistically significant relationships between all factors and student test scores in Math and ELA, except for teacher experience (Table VIII). The influence of each factor on student test scores in this combined linear regression model was less pronounced than in the individual linear regression models for each independent variable. For example, a unit increase in FESR rate yielded an increase of $11 \%$ in Math test score for elementary school students when school factors were analyzed separately. However, a unit increase in FESR rate in the combined regression model can yield an increase of only $6 \%$ in Math test scores (Tables V and VIII). This finding posits the use of a systemic approach when analyzing standardized student test scores. Eliminating any of the contributing factors during exploratory research on this topic can produce erroneous or inadequate conclusions and generate education policies based on fragmented evidence.

\section{E. Interaction Effects Within and Between Teacher, School, and Student Factors}

Table IX shows the interaction effects within independent variables for elementary and middle schools. There is no statistically significant interaction within factors for elementary schools on the Math test scores. The only statistically significant interaction effect within factors for ELA test scores is for student variable (mobility*Attendance, $\mathrm{p}<0.05)$. However, the impact of this interaction is almost negligible. For example, for every unit change in mobility rate, the slope change of the attendance rate on the ELA test score will increase by only 3.38. For middle schools, there is a statistically significant interaction effect within school factors (climate*FESR, $\mathrm{p}=0.001$ ) for Math test scores and within student factors (mobility*Attendance, $\mathrm{p}=0.001$ ) and school factors (climate*FESR, $\mathrm{p}=0.020$ ) for ELA test scores. The impact of all statistically significant interactions within factors on student test scores is inconsequential. This is supported by the lack of additional explanation in variability in test scores after adding the interaction effects within factors to the combined regression model. In order to address improvements in student test scores, this finding suggests that researchers should focus on individual contribution of factors in a combined model structure rather than the interaction within various factors.

Table XI shows the interaction effects between independent variables for elementary and middle schools. There is no statistically significant interaction between variables for elementary schools on the ELA test scores. The only statistically significant interaction effect between variables for Math test scores is between teacher and school factors (teacher*school, $\mathrm{p}=0.020$ ). The impact of this interaction is modest. For example, for every unit change in teacher variable, the slope change of the school variable on the Math test score will decrease by 5.25. For middle schools, there is no statistically significant interaction effect between variables for Math test scores but there is one statistically significant interaction effect between school and student factors for ELA test scores. However, this statistically significant interaction has a very low impact on the ELA test scores. These results were supported by the lack of additional explanation in variability in test scores after adding the interaction effects between variables (Table X).

\section{CONCLUSION}

The statistical results from this study attempt to address the multifaceted antecedents that influence standardized Math and ELA tests in elementary and middle public schools in the state of Georgia. It provides a holistic view to the growing body of research that addresses school accountability as 
demanded by the national and state legislations. The use of standardize tests has dramatically increased after the NCLB act in 2001 and such tests are being used by large number of states as part of school assessment and to drive a better student learning and achievement (National Assessment of Educational Progress, n.d.; Cirino et al., 2018; Vanlaar et al., 2015). Although researchers have studied the individual influence of certain teacher, school, or student factors on student test scores, a void in research to examine the combined effects of factors and the interactions within and between them still exists.

As expected, the individual effect of each factor correlates positively with student test scores when each independent variable is analyzed separately. However, the influence of each factor on student test scores drops dramatically when all three independent variables are included in the regression model. In fact, the effect of teacher experience is found to be not statistically significant in a combined linear regression model. Educators and policymakers should use caution when deriving educational policies based on research findings from studies that explored a single or only a few contributing factors. The second multivariate linear regression model reveals that the interactions within factors are not impactful on student test scores. Adding more factors such as student socio-economic status, cultural background, English language proficiency, and teacher certification level might alter this finding. The third multivariate linear regression model reveals that the interactions between the three independent variables have modest impact on student test scores. Adding more factors for each independent variable has the potential of yielding a different result.

\section{REFERENCES}

Ahmad, N., Ul-Saufie, A. Z., Mohamed, S. A., Ahmat, H., and Zahari, M. F. (2018). The impact of class absenteeism on student's academic performance using regression models. AIP Conference Proceedings, 1974(1), 050012

Balfanz, R. (2007). What your community can do to end its drop-out crisis: Learning from research and practice. Paper presented at the National Summit on America's Silent Epidemic, Washington, DC.

Björk, L. G., Browne-Ferrigno, T., and Kowalski, T. J. (2014). The Superintendent and educational reform in the United States of America. Leadership and Policy in Schools, 13(4), 444-465.

Boyd, D., Grossman, P., Lankford, H., Loeb, S., and Wyckoff, J. (2008). Teacher preparation and student achievement (NBER Working Paper No. W14314). Cambridge, MA: National Bureau of Economic Research.

Brown, G. T. (2017). Purposes and functions of assessment. In G. T. Brown (Eds.), Assessment of student achievement (pp. 1-12).

Buddin, R. \& Zamarro, G. (2009). Teacher qualifications and student achievement in urban elementary schools. Journal of Urban Economics, 66(2), 103-115.

Cassell, J. (2019). Relationships between student attendance and test scores on the Virginia standards of learning tests. ED. D. dissertation.

Chappuis, J., Stiggins, R. J., Chappuis, S., and Arter, J. (2020). Classroom assessment for student learning: Doing it right, using it well. Hoboken, NJ: Pearson Education.

Cirino, P. T., Child, A. E. and Macdonald, K. T. (2018). Longitudinal predictors of the overlap between reading and math skills. Contemporary Educational Psychology, 54, 99-111.

Clotfelter, C. T., Glennie, E., Ladd, H. F., and Vigdor, J. T. (2008). Would higher salaries keep teachers in high-poverty schools? Evidence from a policy intervention in North Carolina. Journal of Public Economics, 92, 1352-1370.

Clotfelter, C. T., Ladd, H. F., and Vigdor, J. L. (2005). Who teaches whom? Race and the distribution of novice teachers. Economics of Education Review, 24, 377-392
Clotfelter, C. T., Ladd, H. F., and Vigdor, J. T. (2007). Teacher credentials and student achievement: Longitudinal analysis with student fixed effects. Economics of Education Review, 26(6), 673-682.

Coenen, J., Cornelisz, I., Groot, W., Brink, H. M., and Klaveren, C. V. (2017). Teacher characteristics and their effects on student test scores: A systematic review. Journal of Economic Surveys. 32(3), 848-877.

Cooper, A. (2017). School resources and student outcomes: Evidence from the state of Illinois [Unpublished MA. Thesis], Illinois State University.

Darling-Hammond, L. (2004). Standards, accountability, and school reform. Teachers College Record, 106(6), 1047-1085.

Dee, T. S. \& Wyckoff, J. (2015). Incentives, selection, and teacher performance: Evidence from IMPACT. Journal of Policy Analysis and Management, 34(2), 267-297.

Dial, J. C. (2008). The effect of teacher experience and teacher degree levels on student achievement in mathematics and communication arts. ED. D. dissertation. Baker University. Retrieved from https://www.bakeru.edu/images/pdf/SOE/EdD_Theses/Dial_Jaime.pd $\underline{f}$

Donnelly, M. \& Gamsu, S. (2018). Home and Away - social, ethnic and spatial inequalities in student mobility, The Sutton Trust.

Dulay, S. \& Karadağ, E. (2017). The effect of school climate on student achievement. The Factors Effecting Student Achievement, 10(12): 199213.

Eddy, L. (2011). The Effect of student mobility on student achievement. ED. D. dissertation.

Egalite, A. J., Kisida, B., and Winters, M. A. (2015). Representation in the classroom: The effect of own-race teachers on student achievement, Economics of Education Review, 45, 44-52.

Fryer, R. G. (2013). Teacher incentives and student achievement: Evidence from New York City public schools. Journal of Labor Economics, 31(2), 373-407.

Gatto, J. T. (2000). The underground history of American education: A school teacher's intimate investigation into the problem of modern schooling. New York: Oxford Village Press.

Georgia Department of Education (n.d.). Georgia Milestones Assessment System. Retrieved from https://www.gadoe.org/CurriculumInstruction-and-Assessment/Assessment/Pages/Georgia-MilestonesAssessment-System.aspx

Gershenson, S. (2016). Linking teacher quality, student attendance, and student achievement. Education Finance and Policy, 11(2), 125-149.

Goldhaber, D. \& Walch, J. (2012). Strategic pay reform: A student outcomes-based evaluation of Denver's ProComp teacher pay initiative. Economics of Education Review, 31, 1067-1083.

Goldhaber, D. (2008). Teachers matter, but effective teacher quality policies are elusive. Handbook of research in education finance and policy, $146-165$.

Goldhaber, D., Lavery, L., and Theobald, R. (2015). Uneven playing field? Assessing the teacher quality pap between advantaged and disadvantaged students. Educational Researcher, 44(5), 293-307.

Golob, T. \& Makarovič, M. (2018). Student mobility and transnational social ties as factors of reflexivity. Social Sciences 7(3): 46-62.

Gottfried, M. A. (2010). Evaluating the relationship between student attendance and achievement in urban elementary and middle schools: An instrumental variables approach. American Educational Research Journal, 47(2), 434-465.

Hanushek, E. A. \& Woessmann, L. (2017). School resources and student achievement: A review of cross-country economic research. Cognitive abilities and educational outcomes, 149-171.

Hanushek, E. A. (1998). Improving student achievement: Is reducing class size the answer? Washington, DC: Progressive Policy Institute.

Hanushek, E. A., Piopiunik, M. and Wiederhold, S. (2018). The value of smarter teachers: International evidence on teacher cognitive skills and student performance. Journal of Human Resources 54(4), 857-899.

Hendricks, M. D. (2014). Does it pay to pay teachers more? Evidence from Texas. Journal of Public Economics, 109, 50-63.

Henry, P. (2007). The case against standardized testing. Minnesota English Journal, 43(2), 39-71.

Hightower, A. M., Delgado, R. C., Lloyd, S. C., Wittenstein, R., Sellers, K., and Swanson, C. B. (2011). Improving student learning by supporting quality teaching: Key issues, effective strategies.

Ho, A. (2014). Variety and drift in the functions and purposes of assessment in K-12 education. Teachers College Record, 116(11), 1-18.

Jackson, C. K., Johnson, R. C., and Persico, C. (2016). The Effects of school spending on educational and economic outcomes: Evidence from school finance reforms. The Quarterly Journal of Economics 131(1), $157-218$.

Jimenez-Castellanos, O. (2010). Relationship between educational resources and school achievement: A mixed method intra-district analysis. The Urban Review 42(4), 351-371. 
Joshi, E., Doan, S., and Springer, M. G. (2018). Student-teacher race congruence: New evidence and insights from Tennessee, AERA Open, 4(4), 1-25.

Kim, A. S., Shakory, S., Azad, A., Popovic, C., and Park, L. (2020). Understanding the impact of attendance and participation on academic achievement. Scholarship of Teaching and Learning in Psychology 6(4), 272.

Ladd, H. F. (2008). Teacher effects: What do we know? Unpublished manuscript, Teacher Quality Conference, Northwestern University.

Loeb, S. \& Page, M. E. (2000). Examining the link between teacher wages and student outcomes: The importance of alternative labor market opportunities and non-pecuniary variation. Review of Economics and Statistics, 82(3), 393-408.

Mansfield, R. K. (2015). Teacher quality and student inequality. Journal of Labor Economics, 33(3), 751-788.

Maxwell, L. E. (2016). School building condition, social climate, student attendance and academic achievement: A mediation model. Journal of Environmental Psychology 46, 206-216.

Maxwell, S., Reynolds, K. J., Lee, E., Subasic, E. and Bromhead, D. (2017). The impact of school climate and school identification on academic achievement: Multilevel modeling with student and teacher data. Frontiers in Psychology, 8, 1-21.

McGahee, W. (2019). The Importance of attending school: A quantitative analysis of the relationship between student attendance and academic achievement. ED \& L. D. dissertation.

National Assessment of Educational Progress. (n.d.). NAEP State Profiles. Retrieved from https://www.nationsreportcard.gov/profiles/stateprofile/overview/GA ?cti=PgTab_OT.

Neem, J. N. (2017). Democracy's schools: The rise of public education in America. Baltimore: Johns Hopkins University Press.

Newland, L. A., DeCino, D. A., Mourlam, D. J., and Strouse, G. A. (2019). School climate, emotions, and relationships: Children's experiences of well-being in the Midwestern US. International Journal of Emotional Education, 11(1), 67-83.

Newton, P. (2017). There is more to educational measurement than measuring: The importance of embracing purpose pluralism. Educational Measurement: Issues and Practice, 36(2), 5-15.

No Child Left Behind Act of 2001, Pub. L. No. 107-110, § 115. Stat, 1425(6), 2002.

Noddings, N. (2017). When school reform goes wrong. New York: Teachers College Press.

Ntobeko, N. (2018). School resources and student achievement: A study of primary schools in Zimbabwe. Educational Research and Reviews, 13(7), 236-248.

Orlich, D. C. (2003). Longitudinal effect of the Washington assessment of student learning (WASL) on student achievement. Education Policy Analysis Archives, 11(18).

Orlich, D. C., \& Gifford, G. (2006). Test Scores, Poverty and Ethnicity: The New American Dilemma. Retrieved from http://www.cha.wa.gov/?q=files/Highstakestesting_poverty_ethnicity. pdf, 2006.

Ostrander, R. R. (2015). School funding: Inequality in district funding and the disparate impact on urban migrant school children. Brigham Young University Education and Law Journal 1, 271-295.

Partelow, L., Spong, A., Brown, C., and Johnson, S. (2017) America needs more teachers of color and a more selective teaching profession. Washington, D.C. Center for American Progress.

Pham, L. D., Nguyen, T. D., and Springer, M. G. (2020). Teacher merit pay and student test scores: A meta-analysis. American Educational Research Journal, 1, 1-57.

Price, M. (2019, March 30). What parents should know about Georgia Milestones tests. The Ledger-Enquirer. Retrieved from https://www.ledgerenquirer.com/news/local/education/article68973067.html

Rhodes, V. L. (2005). Kids on the move: The effects of student mobility on NCLB school accountability ratings. Penn GSE Perspectives in Urban Education Week, 3(3), 1-30.

Rice, J. K. (2013). Learning from experience? Evidence on the impact and distribution of teacher experience and the implications for teacher policy. Education Finance and Policy, 8(3), 332-348.

Savasci, H. S. \& Tomul, E. (2013). The relationship between educational resources of school and academic achievement. International Education Studies, 6(4), 114-123.

Sparks, S. (2016). Student mobility: How it affects learning. Education Week.

Springer, M. G., Ballou, D., and Peng, A. X. (2014). Estimated effect of the teacher advancement program on student test score gains. Education, Finance, and Policy, 9(2): 193-230.
Sun, Y. (2014). Econometrics analysis on factors affecting student achievement. International Journal of Economics and Finance, 6(11), $1-8$.

Tagami. T. (2016, April 30). Five things to know about the new Georgia Milestones tests. The Atlanta Journal-Constitution. Retrieved from https://www.ajc.com/news/local-education/five-things-know-aboutthe-new-georgia-milestones-tests/iSSLGof 8nWbI4NNKHgXqlM/

The Governor's Office of Student Achievement (n.d.): Downloadable data. Retrieved from https://gosa.georgia.gov/report-card-dashboardsdata/downloadable-data.

U.S. Department of Education (n.d.). Every Student Succeeds ACT (ESSA) Retrieved from https://www.ed.gov/essa?src=rn

Vanlaar et al. (2015). Do the teacher and school factors of the dynamic model affect high- and low-achieving student groups to the same extent? A cross-country study. Research Papers in Education, 31(2). 183-211.

Weaver, J. (2019). Teacher factors and student achievement as measured by the act assessment and subsequent teacher perceptions of tho se factors. ED \& L. D. dissertation.

Welsh, R. O. (2016). Student mobility, segregation, and achievement gaps: Evidence from Clark County, Nevada. Urban Education, 53(1), 55-85.

Welsh, R. O. (2017). School hopscotch: A comprehensive review of K-12 student mobility in the United States. Review of Educational Research $87,475-511$.

Wilson, E. K. (2016). Blurred lines: Public school reforms and the privatization of public education. Washington University Journal of Law \& Policy, 51(189), 190-231.

$\mathrm{Xu}, \mathrm{Z}$., Hannaway, J., and Taylor, C. (2011). Making a difference? The effects of teach for America in high school. Journal of Policy Analysis and Management, 30(3), 447- 469.

Yarnell, L. M. \& Bohrnstedt, G. W. (2018). Student-teacher racial match and its association with Black student achievement: An exploration using multilevel structural equation modeling. American Educational Research Journal, 55(2), 287-324.

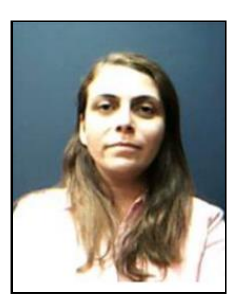

Dr. Saussan Maarouf is Associate Professor of Elementary Childhood at the College of Education and Health Professions at Columbus State University (CSU). Her educational background and certification include a Doctor of Education in Curriculum and Leadership, a Master of Education in Early Childhood, a Reading Endorsement Certification, and a Post-Baccalaureate Certification in Early Childhood from CSU. She earned her bachelor's degree in communication with a specialty in Journalism from the Lebanese University, Beirut - Lebanon. Her current research interests include cognitive development in early childhood, diversity in the classroom, classroom assessment, and program accreditation.

She is currently the Associate Chair, Department of Teacher Education, Leadership, \& Counseling and Program Coordinator, Elementary Education at CSU. She also worked as LiveText Assessment Coordinator at CSU (2012-2015) and was a substitute teacher in the Muscogee County School District, GA, USA (2010-2012). She received "Award of Excellence for Outstanding Participation" in the first annual edTPA conference at the College of Education and Health Professions (CSU, 2014), Dean's Award for Innovation (2018), CSU Teaching Innovation Award Nominee (2018), CSU Excellence Teaching Award nomination (2019), and CSU Teaching Innovation Award nomination (2019). She has done several book reviews and book chapters, published educational research in multiple journals, and presented many conference papers. At a national level, she provides service in education as a CAEP Reviewer and a member of GaPSC Elementary Education Task Force. 